\title{
EDITORIAL
}

\section{Election 2019: unprecedented hope for universal pharmacare}

\author{
Matthew B. Stanbrook MD PhD
}

n Cite as: CMAJ 2019 October 15;191:E1116-7. doi: 10.1503/cmaj.191291

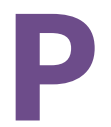

harmacare continues to be the most salient unfinished business of Canada's public health care system since Medicare was introduced more than 50 years ago. In 2011, CMAJ asked "Can Canada get on with national pharmacare already?" 1 The answer has remained no. However, in the 2019 federal election campaign, there are reasons for unprecedented optimism that this answer could change soon - if the people of Canada care enough to ensure that the next government delivers on the long-delayed promise of universal access to essential medications.

For the last decade, pharmacare has taken up unprecedented space in the national conversation. Several factors are likely responsible. The rising cost of medications, and the gap in costs between Canada and peer nations, likely passed a tipping point years ago. This changed public drug coverage from a topic of obscure academic and policy discussion to a subject of household conversation. In response, provincial governments banded together in 2010 as the pan-Canadian Pharmaceutical Alliance to negotiate lower drug prices, thereby creating a key platform both structurally and in the public consciousness - for the introduction of pharmacare. Simultaneously, new health policy research has been published - some of it in $\mathrm{CMAJ}^{2-4}$ - building the case for the feasibility and affordability of national pharmacare and providing evidence for the suitability of different pharmacare models. In June 2019, the federal Advisory Council on the Implementation of National Pharmacare issued its final report, ${ }^{5}$ which recommended a universal, single-payer, public pharmacare program to be implemented gradually between 2022 and 2027 at a cost of $\$ 15.3$ billion a year.

An August 2019 Environics poll reaffirmed that nearly 9 in 10 Canadians support a national pharmacare program that ensures equal access to medications for everyone. ${ }^{6}$ It also confirmed the burden that not having one poses for Canadians: $24 \%$ have rationed, discontinued or not filled prescriptions because of costs; $21 \%$ of those with drug coverage still pay an unaffordable portion out of pocket; and $16 \%$ have no drug coverage, either private or public. Simultaneously, an open letter urging all federal party leaders to commit firmly to pharmacare, signed by more than 1200 health professionals, academics and policy experts, highlighted the need to improve access to medications while reducing costs for households and businesses. ${ }^{7}$ It emphasized that, in 2019, universal pharmacare is neither radical, too expensive, nor in need of further study.

Another factor on pharmacare's side is the relative lack of similarly compelling policy issues to compete for the attention of voters (or politicians seeking to court them). The 2019 election campaign was dominated initially by scandals centred on racism and political integrity, but this discourse has resulted in little movement in public opinion polls. For Canadians seeking substantive policy proposals to guide their choice of the next government, pharmacare has emerged as one of the few issues to which candidates and the media have paid attention.

Consequently, Canadians are finally witnessing a federal election campaign in which most parties are offering substantive policy proposals to implement pharmacare. The Green Party, which campaigned on a promise of universal national pharmacare in the 2015 election, has proposed to implement it immediately at a cost of $\$ 26.7$ billion in the first year, with the expectation that provinces will subsequently pick up a large share of costs. ${ }^{8}$ The New Democratic Party of Canada has campaigned on their April 2019 promise to introduce a universal national pharmacare program by 2020 and would invest $\$ 10$ billion annually, with provinces picking up $60 \%$ of total costs. ${ }^{9}$ The governing Liberal Party of Canada, having commissioned the advisory council's report, promised to bring in pharmacare, guided by the report's recommendations, if re-elected. Yet, in the campaign, they have pledged only a $\$ 6$ billion "down payment" and have not committed to specific timelines. ${ }^{10}$ The party's platform is unclear as to whether provinces will be expected to pick up the balance of the projected costs. ${ }^{11}$ This leaves the Conservative Party of Canada, who previously dismissed the advisory council's report, ${ }^{12}$ as the only major federal party (at the time of writing) not proposing to introduce pharmacare.

Debate over the competing pharmacare proposals will undoubtedly continue to focus on the large upfront costs to government but should not ignore the expected downstream cost savings from decreased government and business expenditures on private coverage, and from decreased health care utilization resulting from better adherence to effective medications. ${ }^{2,3}$ The tendency for politicians - and voters - to embrace short-term thinking at the expense of long-term gains has been the key roadblock to revolutionary changes in public policy. Canadians must not allow that to happen yet again with pharmacare. 
In 1997, a CMAJ editorial observed that the time was not yet right for pharmacare. ${ }^{13}$ It is now clear that pharmacare's time has arrived - if Canadians choose to vote on Oct. 21, 2019, with this issue top of mind - allowing access to the health care Canadians need and deserve.

\section{References}

1. Stanbrook MB, Hébert PC, Coutts J, et al. Can Canada get on with national pharmacare already? CMAJ 2011;183:E1275.

2. Morgan SG, Law M, Daw JR, et al. Estimated cost of universal public coverage of prescription drugs in Canada. CMAJ 2015;187:491-7.

3. Morgan SG, Li W, Yau B, et al. Estimated effects of adding universal public coverage of an essential medicines list to existing public drug plans in Canada. CMAJ 2017;189:E295-302.

4. Morgan SG, Gagnon M-A, Charbonneau M, et al. Evaluating the effects of Quebec's private-public drug insurance system. CMAJ 2017;189:E1259-63.

5. A prescription for Canada: achieving pharmacare for all: final report of the Advisory Council on the Implementation of National Pharmacare. Ottawa: Health Canada; June 2019. Available: www.canada.ca/en/health-canada/corporate/about -health-canada/public-engagement/external-advisory-bodies/implementation -national-pharmacare/final-report.html (accessed 2019 Sept. 26).

6. Young L. 9 in 10 Canadians want national pharmacare: Heart \& Stroke poll. Global News 2019 Sept. 24. Available: https://globalnews.ca/news/5941124/ pharmacare-poll-heart-and-stroke/ (accessed 2019 Sept. 26).

7. In support of universal pharmacare. Pharmacare 2020; 2019 Aug. 15. Available: https://pharmacare2020.ca/our-letter (accessed 2019 Sept. 26).
8. Tunney C. Green Party’s pharmacare plan would cost \$27B in 2020-2021: PBO. CBC News 2019 Sept. 25. Available: www.cbc.ca/news/politics/green-party-pbo -1.5296366 (accessed 2019 Sept. 26).

9. The Canadian Press. Jagmeet Singh highlights NDP's pledge for universal drug coverage. Global News 2019 Sept. 20. Available: https://globalnews.ca/news /5930875/ndp-leader-highlights-pledge-universal-drug-coverage/ (accessed 2019 Sept. 26).

10. Lowrie M. Trudeau pledges $\$ 6 \mathrm{~B}$ to kickstart talks on health care, national pharmacare with provinces. Global News 2019 Sept. 23. Available: https://globalnews .ca/news/5939030/trudeau-pledges-6b-to-kickstart-talks-on-health-care-national -pharmacare-with-provinces/ (accessed 2019 Sept. 26).

11. MacCharles T. Trudeau won't force child care or pharmacare on provinces that don't want it. The Star 2019 Sept. 5. Available: www.thestar.com/politics/federal /2019/09/05/trudeau-wont-force-child-care-or-pharmacare-on-provinces-that-dont -want-it.html (accessed 2019 Sept. 26).

12. Harris K. Advisory council calls for $\$ 15 B$ universal, single-payer pharmacare plan. CBC News 2019 June 12. Available: www.cbc.ca/news/politics/pharmacare -hoskins-recommendations-final-report-1.5171517 (accessed 2019 Sept. 26).

13. Hoey J, Flegel KM. The times they are confusing: What lies ahead for the new health minister and physicians of Canada? CMAJ 1997;157:39-41.

Competing interests: See www.cmaj.ca/site/misc/cmaj_staff.xhtml

Affiliations: Deputy editor, CMAJ; Department of Medicine, University of Toronto, Ont.

Correspondence to: CMAJ editor, cmaj@cmajgroup.ca 